\title{
The effects of ice vest pre-cooling on skin blood flow at rest and during exercise in the heat
}

\author{
Mike Price $^{1 *}$, Matthew Maley ${ }^{2}$ \\ From 15th International Conference on Environmental Ergonomics (ICEE XV) \\ Portsmouth, UK. 28 June - 3 July 2015
}

\begin{abstract}
Introduction
Ice vest pre-cooling has been show to lower rectal temperature during intermittent exercise in hot conditions but only after $40 \mathrm{~min}$ of exercise [1]. The authors suggested that the ice vest may have initiated a strong local cutaneous vasoconstrictor response reducing skin blood flow [2] and thus the cooling potential, until increases in body temperature and skin blood flow occurred later in exercise. Therefore, the purpose of this study was to determine whether ice vest pre-cooling reduces skin blood flow during intermittent exercise in the heat compared to a no cooling control.
\end{abstract}

\section{Methods}

Eight male participants volunteered to take part in the study. Following preliminary tests for peak oxygen uptake and peak power output on a cycle ergometer participants undertook either ice vest pre-cooling in cool conditions (mean (SD) air temperature $19.7(0.4){ }^{\circ} \mathrm{C}$ ) for 20 min (PRE; using Arctic Heat cooling vests) or a no cooling control (CON) prior to 5 min seated rest in the heat and $45 \mathrm{~min}$ of intermittent cycling in the heat (mean (SD) air temperature 35.4 (0.4) ${ }^{\circ} \mathrm{C}, 26.3$ (4.1) \% $\mathrm{RH})$. Participants undertook two further trials involving no exercise to determine the reliability of the cooling procedure. Rectal $\left(\mathrm{T}_{\mathrm{re}}\right)$ and aural $\left(\mathrm{T}_{\mathrm{au}}\right)$ temperature, mean skin temperature $\left(\mathrm{T}_{\mathrm{ms}} ;[3]\right)$, skin blood flow (SkBF; Laser Doppler at the bicep, chest, back and thigh) and ratings of perceived thermal strain (RPTS) were recorded throughout the trial. Data were analysed using two-way analysis of variance with repeated measures on both factors (trial $\times$ time) using SPSS v17.0.

\footnotetext{
* Correspondence: mike.price@coventry.ac.uk

'Department of Applied Science and Health, Coventry University, Coventry, CV1 5FB, UK

Full list of author information is available at the end of the article
}

\section{Results}

Back skin temperature was cooler following PRE (20.3 $\left.(5.0){ }^{\circ} \mathrm{C}\right)$ than for $\mathrm{CON}\left(30.3(1.6){ }^{\circ} \mathrm{C}\right.$; $\left.\mathrm{P}<0.05\right)$ but demonstrated greater intra and inter-individual variation during PRE $\left(\sim 5.0^{\circ}\right)$ when compared to $\operatorname{CON}\left(\sim 1.6^{\circ} \mathrm{C}\right)$. $\mathrm{T}_{\mathrm{au}}$ and $\mathrm{T}_{\mathrm{re}}$ increased by similar amounts during exercise for both PRE and CON $\left(\mathrm{T}_{\mathrm{au}} \sim 1.2{ }^{\circ} \mathrm{C}, \mathrm{T}_{\mathrm{re}} \sim 0.6{ }^{\circ} \mathrm{C}\right.$; $\mathrm{P}>0.05$ ). However, $\mathrm{T}_{\mathrm{au}}$ was cooler from 5 to $25 \mathrm{~min}$ of exercise during PRE $(\mathrm{P}<0.05)$ whereas $\mathrm{T}_{\text {re }}$ was cooler only at $45 \mathrm{~min}$ of exercise during PRE. $\mathrm{T}_{\mathrm{ms}}$ and RPTS were significantly lower during the pre-cooling period (27.1 (2.6) $\left.{ }^{\circ} \mathrm{C} ; 2.6(0.8){ }^{\circ} \mathrm{C}\right)$ compared to $\mathrm{CON}$ (30.9 (1.0) ${ }^{\circ} \mathrm{C}$; $3.6(0.8){ }^{\circ} \mathrm{C}$, respectively; $\left.\mathrm{P}<0.05\right)$ but did not differ during exercise in the heat. RPTS values were consistent between and within participants. Although no trial $\times$ time interactions were observed for SkBF sites a main effect for trial for the back site indicated a decrease in SkBF during the pre-cooling period $(-40$ (26) \%) when compared to $\operatorname{CON}(9$ (45) \%; P $<0.05)$.

\section{Discussion}

Ice vest pre-cooling resulted in decreased $\mathrm{T}_{\mathrm{au}}$ and $\mathrm{T}_{\mathrm{re}}$, but at different time points, during intermittent cycle exercise in the heat. Back skin temperature responses to cooling were varied and likely explained by the closeness of fit of commercially available ice vests with subsequent effects on local skin blood flow.

\section{Conclusion}

The delay in reducing $\mathrm{T}_{\mathrm{re}}$ following ice vest pre-cooling may be a result of deep body temperature measurement site rather than changes in local skin blood flow per se.

\footnotetext{
Authors' details

${ }^{1}$ Department of Applied Science and Health, Coventry University, Coventry, CV1 5FB, UK. '2 Extreme Environments Laboratory, Department of Sport and Exercise Science, University of Portsmouth, Portsmouth, UK.
} 


\section{References}

1. Price MJ, Boyd C, Goosey-Tolfrey VL: The physiological effects of pre- and mid-event cooling during intermittent running in the heat in elite female soccer players. Applied Physiology, Nutrition and Metabolism 2009, 34(5):942-949.

2. Petrofsky JS, Al-Malty AM, Prowse M: Relationship between multiple stimuli and skin blood flow. Med Sci Monit 2008, 14(8):CR399-405, 2008 Aug.

3. Ramanathan NLA: A new weighting system for mean surface temperature of the human body. J Appl Physiol 1964, 19:531-534.

\section{doi:10.1186/2046-7648-4-S1-A127}

Cite this article as: Price and Maley: The effects of ice vest pre-cooling on skin blood flow at rest and during exercise in the heat. Extreme Physiology \& Medicine 2015 4(Suppl 1):A127.

\section{Submit your next manuscript to BioMed Central} and take full advantage of:

- Convenient online submission

- Thorough peer review

- No space constraints or color figure charges

- Immediate publication on acceptance

- Inclusion in PubMed, CAS, Scopus and Google Scholar

- Research which is freely available for redistribution

Submit your manuscript at www.biomedcentral.com/submit 